\title{
Vanillin oxime inhibits lung cancer cell proliferation and activates apoptosis through JNK/ERK-CHOP pathway
}

\author{
Jie Shen ${ }^{1}$ and Zhixiang $\mathrm{Su}^{2 \text {,* }}$ \\ ${ }^{1}$ Department of Respiratory, Yan'an People's Hospital, Yan'an, Shaanxi 716000, ${ }^{2}$ Department of Medical Oncology Hospital Unit 3, Shaanxi Provincial Cancer \\ Hospital, Xian 710061, China
}

\section{ARTICLE INFO}

Received June 30, 2020

Revised September 16, 2020

Accepted September 26, 2020

\section{*Correspondence}

Zhixiang Su

E-mail: szx7809@sina.com

Key Words

Apoptosis

Death receptors

Lung cancer

Natural products

Vanillin oxime

\begin{abstract}
Lung cancer despite advancement in the medical field continues to be a major threat to human lives and accounts for a high proportion of fatalities caused by cancers globally. The current study investigated vanillin oxime, a derivative of vanillin, against lung cancer cells for development of treatment and explored the mechanism. Cell viability changes by vanillin oxime were measured using MTT assay. Vanillin oxime-mediated apoptosis was detected in A549 and NCI-H2170 cells at $48 \mathrm{~h}$ of exposure by flow cytometry. The CEBP homologous protein (CHOP) and death receptor 5 (DR5) levels were analysed by RT-PCR and protein levels by Western blotting. Vanillin oxime in concentration-dependent way suppressed A549 and $\mathrm{NCl}-\mathrm{H} 2170$ cell viabilities. On exposure to 12.5 and $15 \mu \mathrm{M}$ concentrations of vanillin oxime elevated Bax, caspase-3, and -9 levels in A549 and NCI-H2170 cells were observed. Vanillin oxime exposure suppressed levels of Bcl-2, survivin, BCl-xL, CFLIP, and IAPs proteins in A549 and $\mathrm{NCl}-\mathrm{H} 2170$ cells. It stimulated significant elevation in DR4 and DR5 levels in $\mathrm{A} 549$ and $\mathrm{NCl}-\mathrm{H} 2170$ cells. In A549 and $\mathrm{NCl}-\mathrm{H} 2170$ cells vanillin oxime exposure caused significant $(p<0.05)$ enhancement in CHOP and DR5 mRNA expression. Vanillin oxime exposure of A549 and NCI-H2170 cells led to significant ( $p<$ 0.05 ) enhancement in levels of phosphorylated extracellular-signal-regulated kinase and c-Jun $\mathrm{N}$-terminal kinase. Thus, vanillin oxime inhibits pulmonary cell proliferation via induction of apoptosis through tumor necrosis factor-related apoptosis-inducing ligand (TRAIL) mediated pathway. Therefore, vanillin oxime may be studied further to develop a treatment for lung cancer.
\end{abstract}

\section{INTRODUCTION}

Lung cancer despite advancement in the medical field continues to be a major threat to human lives and accounts for a high proportion of fatalities caused by cancers globally [1]. Small cell and non-small cell lung cancers (NSCLC) respectively contribute $15 \%$ and $85 \%$ of the total pulmonary cancer patients diagnosed worldwide [2]. The rate of 5 -year survival for patients with NSCLC is only $15 \%$ even after huge advancement in chemo- and radiation therapies for [3]. Development of more efficient treatment strategies for pulmonary cancer are thereby immediately required to improve survival of patients.

Most crucial way to arrest tumor development and inhibit carcinoma progression is via induction of apoptosis. Majority of the researchers are searching for molecules which activate pathways involved in apoptosis and therefore accelerate death of cells. Selective carcinoma cell death is activated by tumour necrosis factorrelated apoptosis-inducing ligand (TRAIL) which is an apoptosis inducing ligand related with tumor necrosis factor $[4,5]$. In activating death TRAIL interacts with receptors namely, DR4 and DR5 present in membranes via its ligands [6]. Moreover, TRAIL also influences decoy receptors including DcR-1 and DcR-2 in

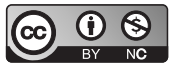

This is an Open Access article distributed under the terms of the Creative Commons Attribution Non-Commercial License, which permits unrestricted non-commercial use, distribution, and reproduction in any medium, provided the original work is properly cited. Copyright @ Korean J Physiol Pharmacol, pISSN 1226-4512, elSSN 2093-3827
Author contributions: Z.S. conceived and designed the study. J.S. performed the experimental work. Both the authors performed literature survey, analyzed the data and wrote the paper. 
addition to osteoprotegerin which are devoid of transmembrane domain [7]. On interacting with DR4 and DR5, TRAIL causes induction of death signal via activation of both initiator as well as effector caspases leading to apoptosis $[8,9]$. Elevated decoy receptor levels and suppressed DRs are associated with cell resistance to TRAIL mediated apoptosis $[9,10]$. Besides, excessive FLICElike inhibitory proteins (cFLIP) along with apoptosis inhibitor proteins (IAPs) also lead to resistance to TRAIL induced death [11].

Four-hydroxy-3-methoxybenzaldehyde (Fig. 1), commonly called as vanillin is present in the seeds of Vanilla planifolia plant. The compound initially used as flavoring agent was latter reported to possess anti-microbial, anti-mutagenic and anti-inflammatory properties in rodent and human models [12-15]. Vanillin targets nuclear factor- $\mathrm{\kappa} B$ expression and activity of MMP's to arrest migration and invasiveness of liver carcinoma cells [16]. In pulmonary cancer cells angiogenesis and development of lamellipodia is inhibited by vanillin by targeting PI3K activation [1719]. Signals to induce apoptosis in breast and cervical carcinoma cells are initiated by vanillin to inhibit tumor growth [17-19]. The current study investigated vanillin oxime, a derivative of vanillin against lung cancer cells for development of treatment and explored mechanism.

\section{METHODS}

\section{Drugs and reagents}

Vanillin oxime (Cas number S539570; purity 99\%) was supplied by Merck Chemicals. Dimethyl sulfoxide (DMSO) and many other chemicals were provided by the Sigma-Aldrich (St Louis, MO, USA).

\section{Cell lines}

Lung cancer cell lines (A549 and NCI-H2170) and normal epithelial cells (BEAS-2B) were supplied by the ATCC, Rockville,
MD, USA and maintained in RPMI-1640 medium provided with $10 \% \mathrm{FBS}$ at $37^{\circ} \mathrm{C}$ in incubator with $5 \% \mathrm{CO}_{2}$ atmosphere. Supplementation of medium was made with penicillin (100 units/ml) and streptomycin $(100 \mu \mathrm{g} / \mathrm{ml})$.

\section{Cell viability assay}

The A549, BEAS-2B and NCI-H2170 cell viability changes by vanillin oxime were measured using 3-(4,5-dimethylthiazol2-yl)2,5-diphenyltetrazolium bromide (MTT) assay. Cells maintained for $24 \mathrm{~h}$ in RPMI-1640 medium at $2 \times 10^{6}$ cells/well density in 96-well plates were exposed for $48 \mathrm{~h}$ to $5,7.5,10,12.5,15$, 17.5 , and $20 \mu \mathrm{M}$ concentrations of vanillin oxime. Medium was changed and then MTT $(20 \mu \mathrm{l} ; 0.5 \mathrm{mg} / \mathrm{ml})$ solution was poured in each well to incubate cells for $4 \mathrm{~h}$. Afterwards, DMSO (120 $\mu \mathrm{l})$ was added to the wells and optical density was recorded by Multiskan Spectrometer (Vantaa, Finland) at $574 \mathrm{~nm}$.

\section{Analysis of apoptosis}

Vanillin oxime-mediated apoptosis was detected in A549 and NCI-H2170 cells at $48 \mathrm{~h}$ of exposure by flow cytometry. Exposure of cells to 12.5 and $15 \mu \mathrm{M}$ concentrations of vanillin oxime was followed by treatment with annexin V-FITC reagent $(5 \mu \mathrm{l})$ for 35 $\mathrm{min}$ at room temperature. Apoptotic cell fraction was analysed using FACS Calibur flow cytometer (BD Biosciences, Franklin Lakes, NJ, USA).

\section{Western blotting}

The A549 and NCI-H2170 cells were exposed to 12.5 and 15 $\mu \mathrm{M}$ concentrations of vanillin oxime for $48 \mathrm{~h}$. After exposure, incubation was carried with ice-cold $(0.5 \mathrm{ml})$ lysate buffer (consisting of $\mathrm{NaCl}[5 \mathrm{M}], \mathrm{NaVO}_{4}[0.2 \mathrm{M}]$, Nonidet P-40 [10\%], EGTA [0.1 M], EDTA [0.5 M], $\mathrm{PhCH}_{2} \mathrm{SO}_{2} \mathrm{~F}$ [0.1 M], NaF [1 M], HEPES [1 $\mathrm{M}]$ aprotinin $[2 \mu \mathrm{g} / \mathrm{ml}]$ and leupeptin $[2 \mu \mathrm{g} / \mathrm{ml}])$ for $45 \mathrm{~min}$. After centrifugation at $12,000 \times \mathrm{g}$ at $4^{\circ} \mathrm{C}$ protein level in supernatant separated from the lysates was estimated by Bio-Rad assay (Bio-

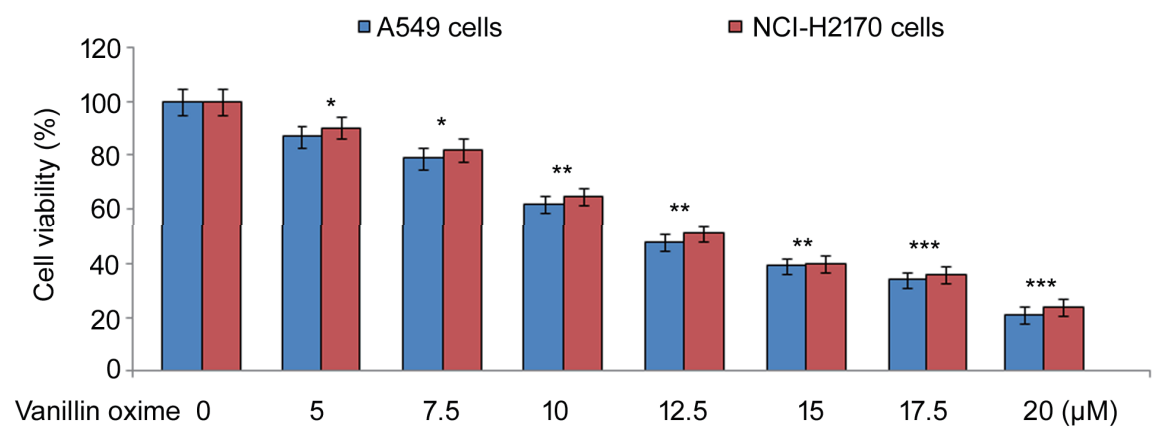

Fig. 1. Effect of vanillin oxime on A549 and NCI-H2170 cells. Vanillin oxime at 5, 7.5, 10, 12.5, 15, 17.5, and $20 \mu \mathrm{M}$ concentrations was mixed in RPMI to determine $\mathrm{A} 549$ and $\mathrm{NCI}-\mathrm{H} 2170$ cell viability changes at $48 \mathrm{~h}$ by MTT assay. MTT, 3-(4,5-dimethylthiazol-2-yl)2,5-diphenyltetrazolium bromide. ${ }^{*} \mathrm{p}<$ 0.05 and $^{* *} \mathrm{p}<0.01$ vs. control, ${ }^{* * *} \mathrm{p}<0.018$. 
Rad, Hercules, CA, USA). Fractionation of $60 \mu$ g protein samples on SDS-PAGE was followed by transfer to PVDF membranes (Millipore, Bedford, MA, USA). Probing of proteins was carried out by over-night membrane incubation at $4^{\circ} \mathrm{C}$ with primary antibodies. Washing membranes with TBST was followed by incubating the blots for $1 \mathrm{~h}$ with anti-rabbit secondary antibodies conjugated to horseradish peroxidase. Detection as well as analysis of the bands was carried out using the ECL western blot analysing system (Biotech Inc., USA). The primary antibodies used were against JNK, p-JNK, caspase-3, -8, -9, CHOP, Bcl-xL, ERK1/2, pERK1/2, DR4, DR5, survivin, Bax, cFLIP, xIAP (Cell Signaling Technology, Danvers, MA, USA).

\section{Determination of DR4 and DR5 levels}

Mouse anti-human antibodies against DR4 as well as DR5 which are conjugated to the phycoerythrin (Minneapolis, $\mathrm{MN}$, USA) were used for analysis death receptors in A549 and NCI$\mathrm{H} 2170$ cells. The cells at $2 \times 10^{6}$ cells/well distribution were exposed to 12.5 and $15 \mu \mathrm{M}$ concentrations of vanillin oxime for 48 h. Then incubation with antibodies was done for $50 \mathrm{~min}$ at $4^{\circ} \mathrm{C}$ to analyse receptor expression using flow cytometry.

\section{RT-PCR analysis}

To determine levels of CHOP and DR5 mRNA in A549 and NCI-H2170 cells after exposure to 12.5 and $15 \mu \mathrm{M}$ vanillin oxime RT-PCR was used. From A549 and NCI-H2170 cells total RNA was isolated at $48 \mathrm{~h}$ of vanillin oxime exposure by TRIzol reagent (Invitrogen, Carlsbad, CA, USA). Primer sequences used for PCR were as follows: CHOP, forward 5'CAACTGCAGAGATGGCAGC TGA-3' and reverse 5'-CTGATGCTCCCAATT GTTCAT-3'; DR5, forward 5'-AAGACCCTTGTG CTCGTTGTC-3' and reverse 5'-GACACATT CGATGTCACTCCA-3'; and GAPDH, forward 5'-GTCTTCACCACCATGGAG3' and reverse 5'-CCACCCTGTTGCTGTAGC3'.

\section{siRNA transfection}

Effect of silencing CHOP and DR5 on A549 and NCI-H2170 cells followed by exposure to vanillin oxime was also studied. Transfection of $30 \mathrm{nM}$ siRNA (oligonucleotides) to A549 and NCI-H2170 cells was performed using lipofectamine 2000 (Invitrogen) as per the manual procedure [20]. Then cells were exposed for $48 \mathrm{~h}$ to 12.5 and $15 \mu \mathrm{M}$ vanillin oxime followed by western blotting to detect changes in $\mathrm{CHOP}$ and DR5 expression.

\section{Statistical analysis}

The data expressed are mean \pm standard deviation of the measurements made in triplicates. To analyse data statistically SPSS software (IBM Corp.) was used. Differences between groups were statistically determined by one-way ANOVA and Duncan's test (DMRT). The values at $\mathrm{p}<0.05$ were taken to be statistically significant.

\section{RESULTS}

\section{Vanillin oxime is cytotoxic}

A549 and NCI-H2170 cells were exposed to vanillin oxime at $5,7.5,10,12.5,15,17.5$, and $20 \mu \mathrm{M}$ concentrations (Fig. 1). Vanillin oxime in concentration dependent way suppressed A549 and NCI-H2170 cell viabilities at $48 \mathrm{~h}$. At 5 and $20 \mu \mathrm{M}$ concentrations vanillin oxime exposure reduced A549 cell viability to 87 and $21 \%$, respectively. Viabilities of NCI-H2170 cells were suppressed to 90 and $24 \%$, respectively on exposure to 5 and $20 \mu \mathrm{M}$ concentrations vanillin oxime. As viabilities of A549 and NCI$\mathrm{H} 2170$ cells were reduced to intermediate level at 12.5 and $20 \mu \mathrm{M}$ therefore only these two concentrations were chosen for further studies.

\section{Vanillin oxime is apoptotic agent}

Vanillin oxime mediated apoptosis in A549 and NCI-H2170 cells at $48 \mathrm{~h}$ was detected by Annexin V staining (Fig. 2). Exposure to 12.5 and $15 \mu \mathrm{M}$ concentrations of vanillin oxime increased A549 and NCI-H2170 cell apoptosis significantly (p < 0.05 ). Vanillin oxime at 12.5 and $15 \mu \mathrm{M}$ led to apoptosis in 48.23 and $63.91 \%$ A549 cells, respectively. In NCI-H2170 cells apoptosis reached to 45.14 and $59.37 \%$, respectively on exposure to vanillin oxime at 12.5 and $15 \mu \mathrm{M}$ concentrations.

\section{Vanillin oxime promoted pro-apoptotic proteins}

In vanillin oxime exposed A549 and NCI-H2170 cells proapoptotic protein levels were assayed at $48 \mathrm{~h}$ by western blotting (Fig. 3). On exposure to 12.5 and $15 \mu \mathrm{M}$ concentrations of vanillin oxime elevated cleaved caspase-3 and -9 levels in A549 and NCI-H2170 cells were observed. In vanillin oxime (12.5 and 15 $\mu \mathrm{M})$ exposed A549 and NCI-H2170 cells Bax level was also higher relative to untreated cells.

\section{Vanillin oxime targeted survival protein expression}

Vanillin oxime exposure at 12.5 and $15 \mu \mathrm{M}$ concentrations suppressed levels of Bcl-2, survivin, Bcl-xL, cFLIP and IAPs proteins in A549 and NCI-H2170 cells (Fig. 4). In control A549 and NCI-H2170 cells Bcl-2, survivin, Bcl-xL, cFLIP and IAPs protein levels were observed to be markedly higher compared to vanillin oxime treated cells. In A549 and NCI-H2170 cells protein expression was determined at $48 \mathrm{~h}$ using Western blotting assay. 

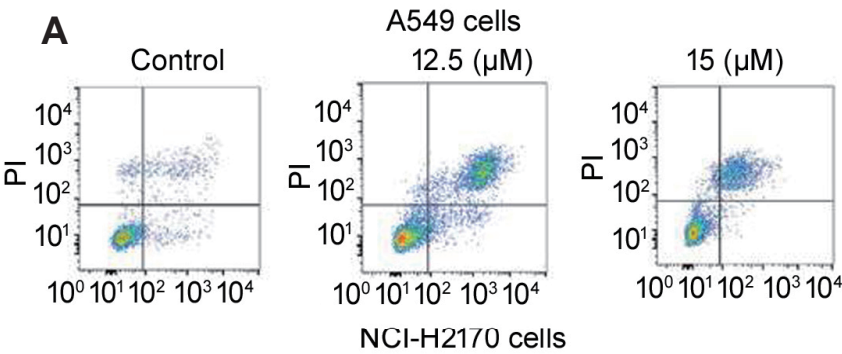

B
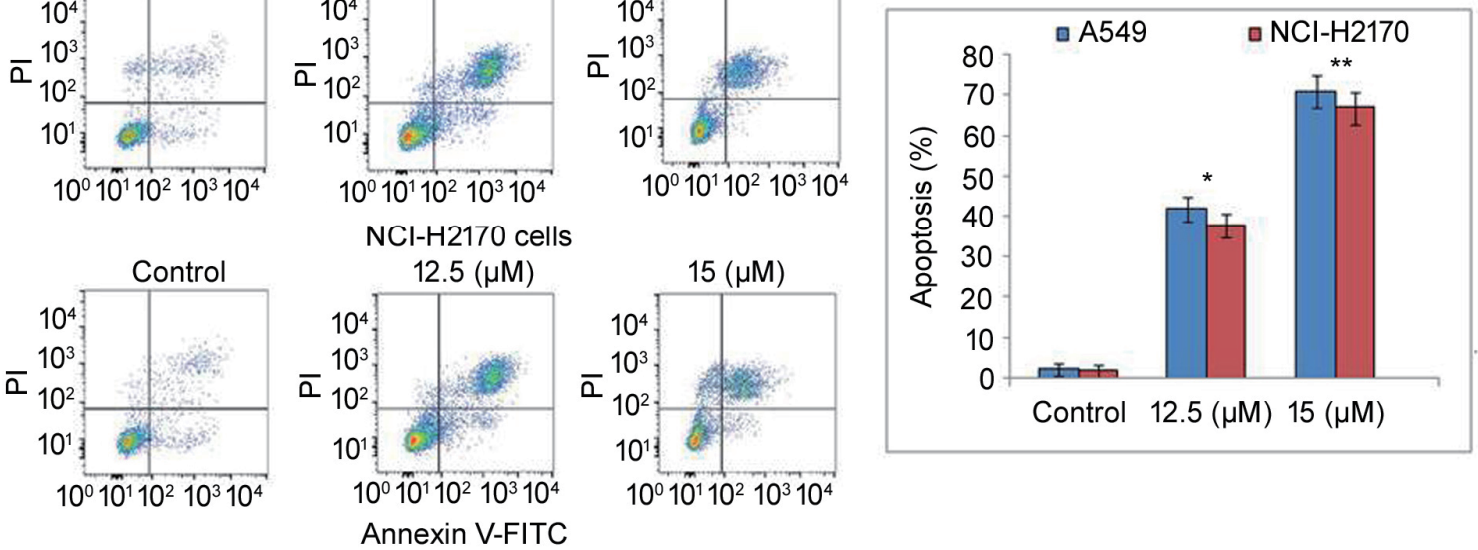

Fig. 2. Effect of vanillin oxime on $\mathbf{A} 549$ and $\mathrm{NCl}-\mathrm{H} 2170$ cell apoptosis. (A) Vanillin oxime at 12.5 and $15 \mu \mathrm{M}$ concentrations was mixed in RPMI to determine $\mathrm{A} 549$ and $\mathrm{NCl}-\mathrm{H} 2170$ cell apoptosis induction at $48 \mathrm{~h}$ by flow cytometry. (B) Quantification of the data obtained from flow cytometry. Pl, propidium iodide. ${ }^{*} p<0.05$ and ${ }^{* *} p<0.01$ vs. control.
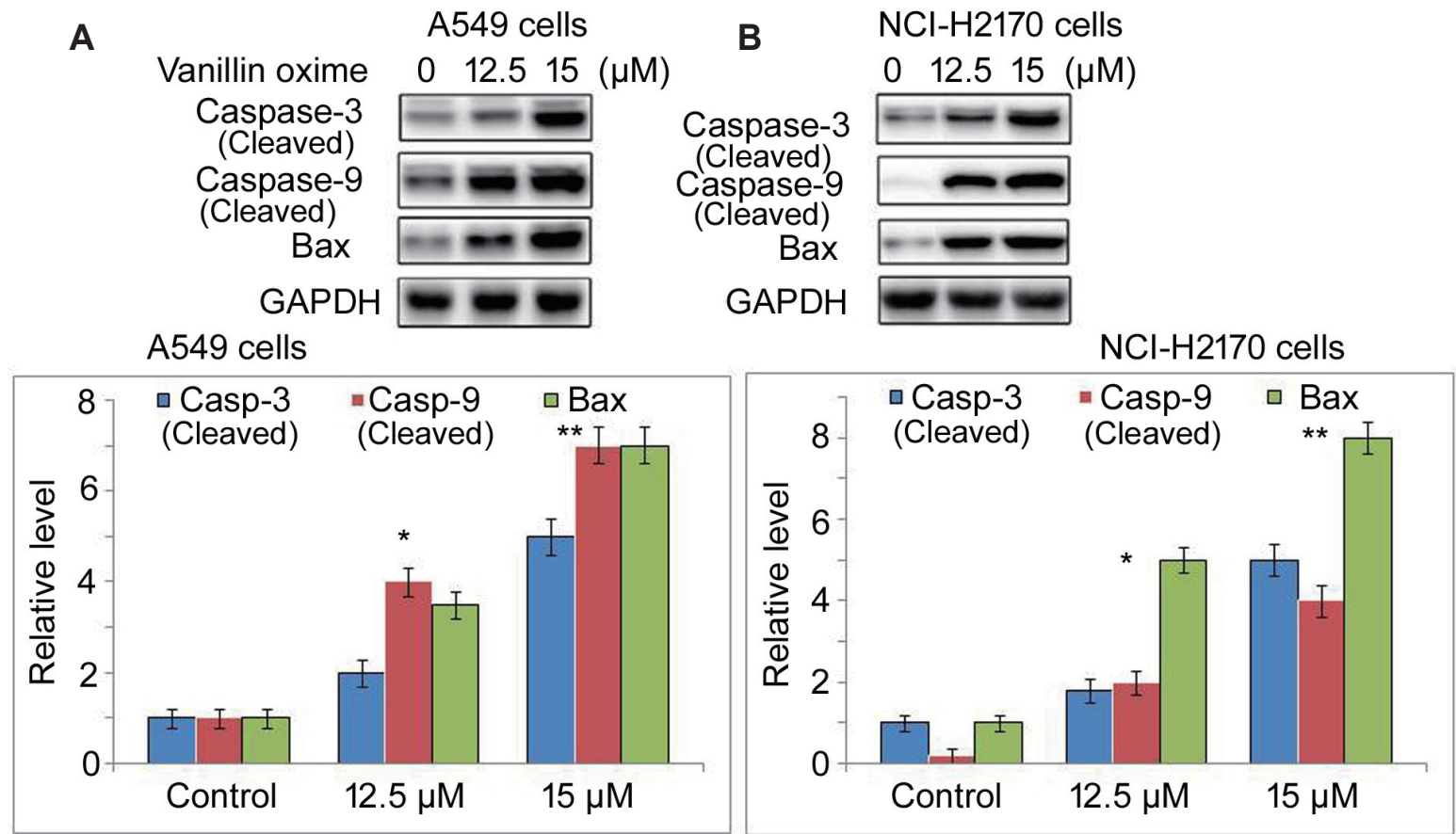

Fig. 3. Effect of vanillin oxime on pro-apoptotic proteins. (A) Vanillin oxime at 12.5 and $15 \mu \mathrm{M}$ concentrations was mixed in RPMI to determine cleaved caspase-3, -9 and Bax expression in A549 and NCI-H2170 cells at $48 \mathrm{~h}$ by Western blotting. (B) Proteins bands were quantified. * $\mathrm{p}<0.05$ and ** $\mathrm{p}<0.01$ vs. control.

\section{Vanillin oxime up-regulated DR4 and DR5}

In A549 and NCI-H2170 cells exposure to 12.5 and $15 \mu \mathrm{M}$ concentrations of vanillin oxime was followed by DR4 and DR5 expression assessment (Fig. 5). Vanillin oxime exposure stimulated significant elevation in DR4 and DR5 levels in A549 and NCIH2170 cells at 48 h. Promotion in DR4 and DR5 levels was higher on treatment with $15 \mu \mathrm{M}$ vanillin oxime compared to $12.5 \mu \mathrm{M}$ concentration.

\section{Vanillin oxime promoted CHOP expression}

In A549 and NCI-H2170 cells vanillin oxime exposure at 12.5 and $15 \mu \mathrm{M}$ doses caused significant $(\mathrm{p}<0.05)$ enhancement in CHOP and DR5 expression (Fig. 6). Vanillin oxime exposure at 12.5 and $15 \mu \mathrm{M}$ doses also elevated CHOP protein level in A549 
A

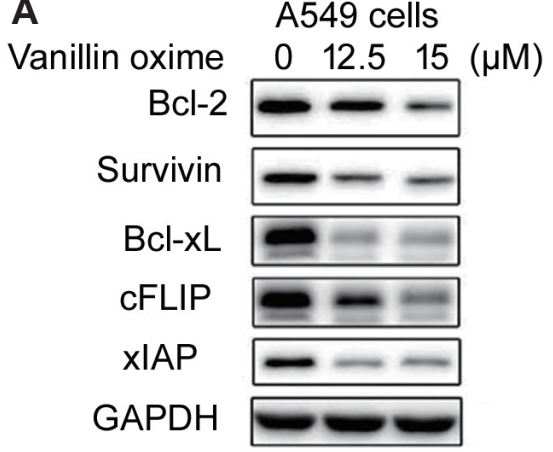

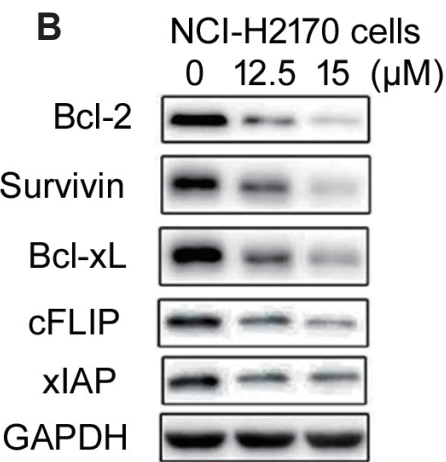

Fig. 4. Effect of vanillin oxime on survival proteins. Vanillin oxime at 12.5 and $15 \mu \mathrm{M}$ concentrations was mixed in RPMI to assess survival proteins levels in (A) A549 and (B) NCl-H2170 cells by western blotting. In vanillin oxime treated cells protein expression was determined at $48 \mathrm{~h}$ using Western blotting assay.

A A549 cells

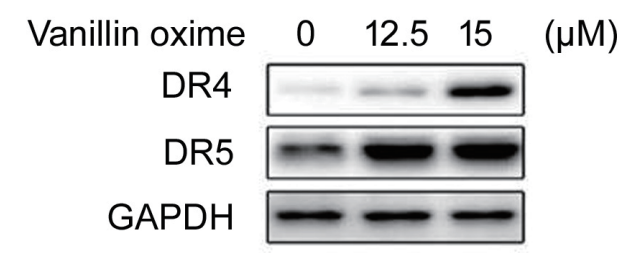

A549 cells

\section{B}

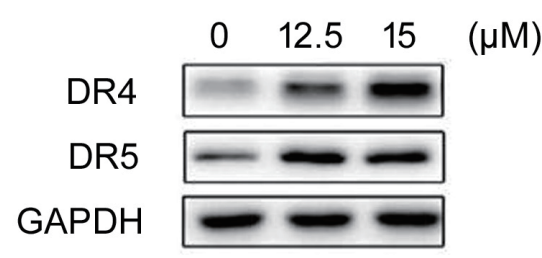

$\mathrm{NCl}-\mathrm{H} 2170$ cells
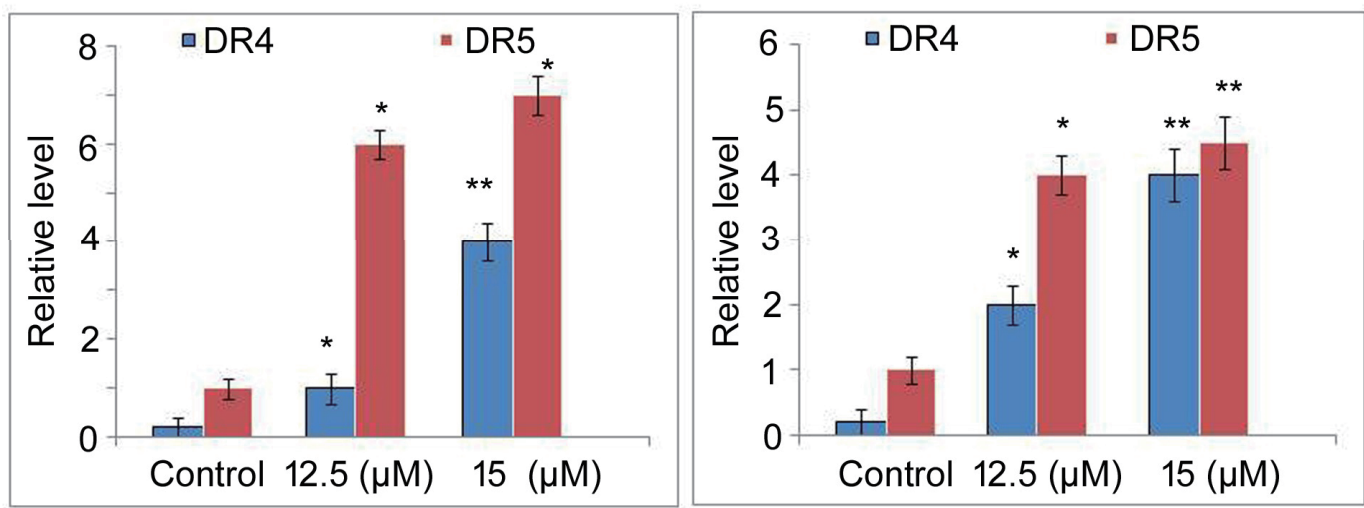

Fig. 5. Effect of vanillin oxime on DR4 and DR5 levels. Vanillin oxime at 12.5 and $15 \mu \mathrm{M}$ concentrations was mixed in RPMI to assess DR4 and DR5 levels in (A) A549 and (B) NCl-H2170 cells at $48 \mathrm{~h}$ by Western blotting. ${ }^{*} \mathrm{p}<0.05$ and ${ }^{* *} \mathrm{p}<0.01$ vs. control.

and NCI-H2170 cells. However, in vanillin oxime exposed A549 and NCI-H2170 cells CHOP and DR5 expression was significantly lowered on CHOP-siRNA transfection (Fig. 7).

\section{Vanillin oxime induced ERK and JNK activation}

Vanillin oxime exposure of A549 and NCI-H2170 cells at 12.5 and $15 \mu \mathrm{M}$ doses led to significant $(\mathrm{p}<0.05)$ enhancement in levels of phosphorylated ERK and JNK (Fig. 8). Enhancement in p-ERK and p-JNK levels by vanillin oxime was higher at 15 $\mu \mathrm{M}$ doses relative to $12.5 \mu \mathrm{M}$ concentration. Treatment of A549 and NCI-H2170 cells with JNK inhibitor (SP600125) as well as ERK1/2 inhibitor (PD98059) led to prominent reduction in vanil- lin oxime induced DR5 and DR4 levels (Fig. 9).

\section{DISCUSSION}

Vanillin was shown to possess anticarcinogenic activity in rats and as antimutagen in several in vitro models $[13,21]$. It potentiates cytotoxicity of many DNA-damaging agents such as cisplatin [22] and mitomycin C [23]. Moreover, vanillin demonstrated anti-metastatic activity for 4T1-mouse mammary carcinoma and inhibited invasiveness and migration of tumor cells in vitro [18]. Resistance to death induced by TRAIL is linked with the higher survival protein levels including, cFLIP, Bcl-2, survivin 

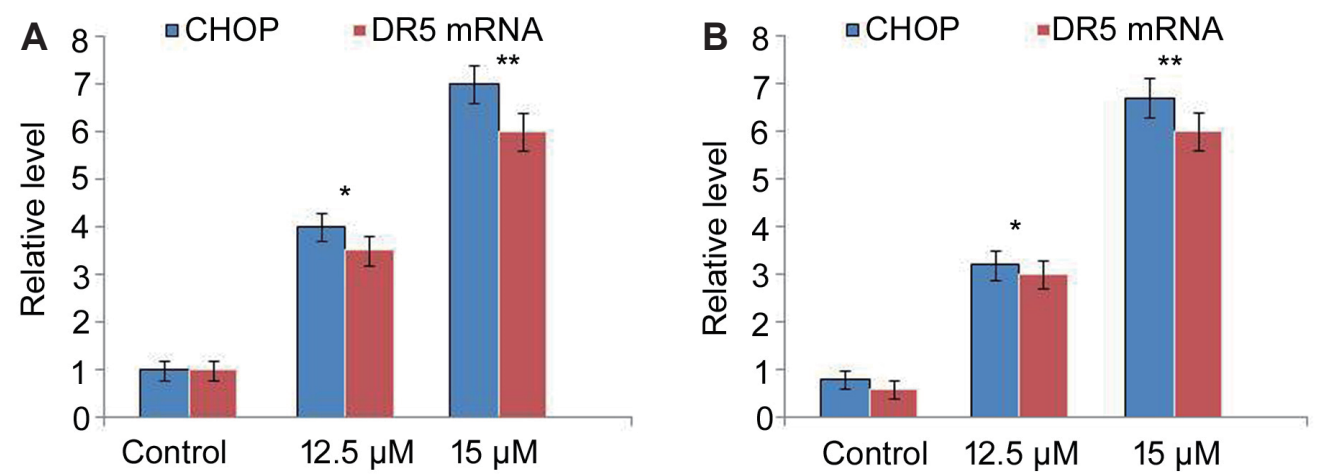

Fig. 6. Effect of vanillin oxime on CHOP and DR5 levels. (A) Vanillin oxime at 12.5 and $15 \mu \mathrm{M}$ concentrations was mixed in RPMI to assess CHOP and DR5 levels in A549 and NCI-H2170 cells at $48 \mathrm{~h}$ by RT-PCR assay. (B) CHOP protein bands were assayed by Western blotting. ${ }^{*} p<0.05$ and ${ }^{* *} p<0.01$ vs. control.
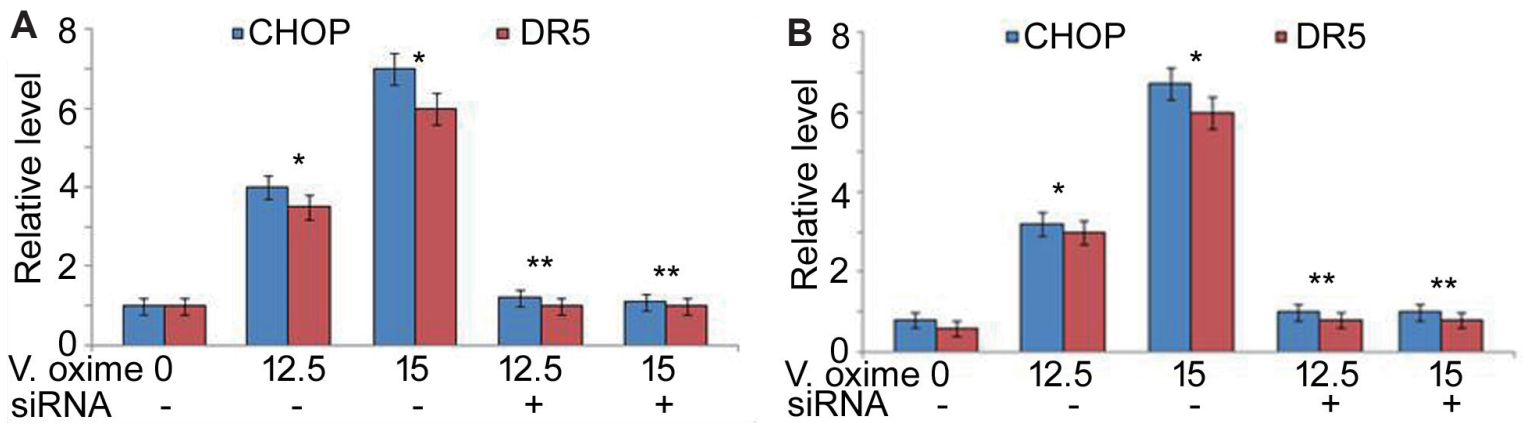

Fig. 7. Effect of CHOP siRNA on vanillin oxime induced CHOP and DR5 levels. Vanillin oxime at 12.5 and $15 \mu \mathrm{M}$ concentrations was mixed in RPMI to assess CHOP and DR5 levels in CHOP siRNA transfected (A) A549 and (B) NCI-H2170 cells. ${ }^{*} p<0.05$ and ${ }^{* *} \mathrm{p}<0.01$ vs. control.

A

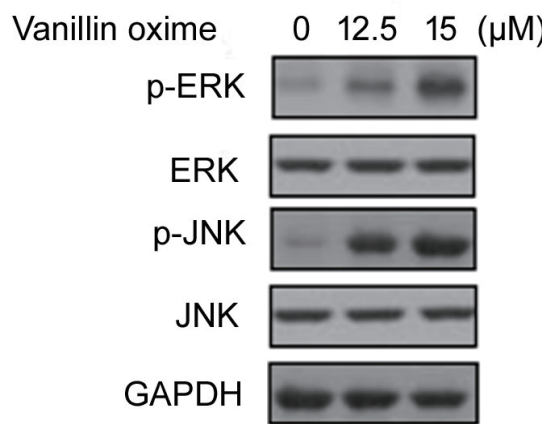

B NCl-H2170 cells

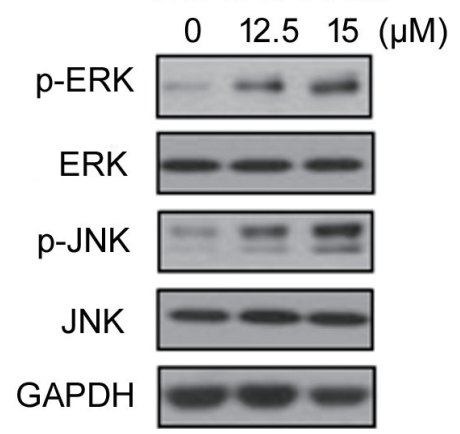

Fig. 8. Effect of vanillin oxime on ERK and JNK activation. Vanillin oxime at 12.5 and $15 \mu \mathrm{M}$ concentrations was mixed in RPMI to assess p-ERK and p-JNK levels in (A) A549 and (B) NCl-H2170 cells by Western blotting.

and Bcl-xL in carcinoma cells $[24,25]$. Targeting expression of these proteins which are associated with resistance to death induced by TRAIL has prominent potential in cancer treatment strategies. In the present study vanillin oxime suppressed A549 and NCI-H2170 cell viabilities in concentration dependent way. Thus, vanillin oxime was found to be cytotoxic agent for A549 and NCI-H2170 cells from initial MTT studies. Further studies demonstrated that exposure to vanillin oxime increased A549 and NCI-H2170 cell apoptosis significantly $(\mathrm{p}<0.05)$. In vanillin oxime exposed A549 and NCI-H2170 cells caspase-3 and -9 levels were enhanced excessively relative to untreated cells. Moreover, vanillin oxime exposure of A549 and NCI-H2170 cells also raised Bax level significantly. Vanillin oxime exposure suppressed levels of cFLIP, Bcl-2, survivin and Bcl-xL proteins in dose-based way in A549 and NCI-H2170 cells. Therefore, vanillin oxime exhibited toxicity for A549 and NCI-H2170 cells by inducing apoptosis through targeting anti-apoptotic proteins.

Plant derived compounds promote death of carcinoma cells via 

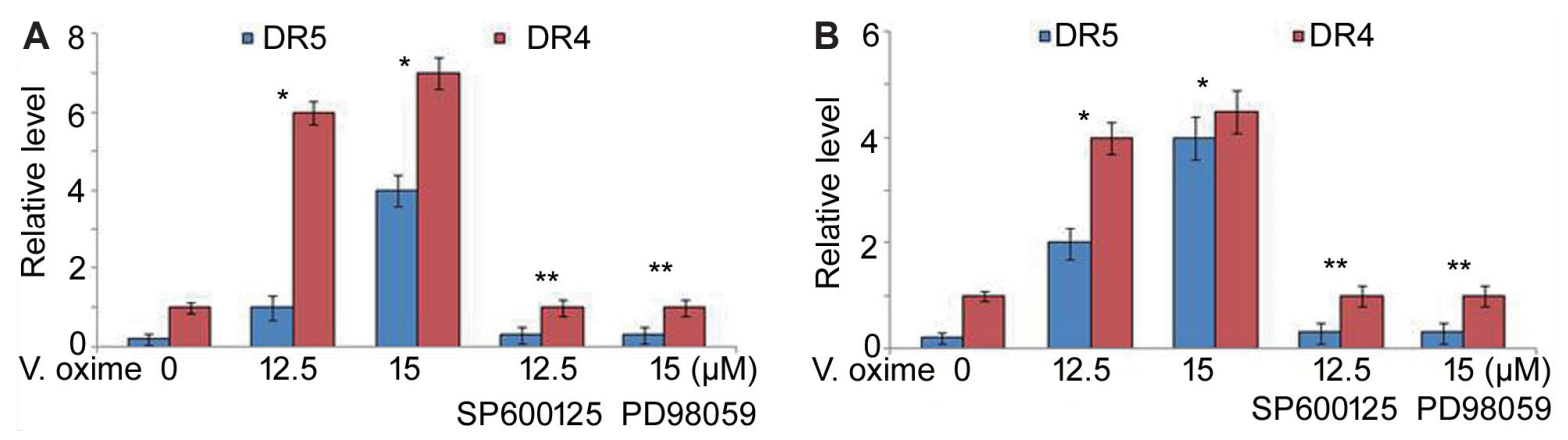

Fig. 9. Effect of ERK and JNK inhibitors on vanillin oxime induced DR5 and DR4 levels. Vanillin oxime at 12.5 and $15 \mu \mathrm{M}$ concentrations was mixed in RPMI to assess DR5 and DR4 in SP600125 and PD98059 treated (A) A549 and (B) NCl-H2170 cells by RT-PCR. ${ }^{*} p<0.05$ and ${ }^{* *} p<0.01$ vs. control.

TRAIL-mediated pathway through targeting survival proteins and elevation of caspases [26,27]. Resistance of cancers to TRAIL is related with dysregulated DR4 and DR5 levels and thereby upregulation induces cell death $[28,29]$. In the present study vanillin oxime exposure stimulated significant elevation in DR4 and DR5 levels in A549 and NCI-H2170 cells. Moreover, elevation of DR4 and DR5 levels was higher on exposure to higher doses of vanillin oxime compared to lower concentrations.

The DR 5 level is regulated by a transcriptional factor known as $\mathrm{C} / \mathrm{EBP}$ homologous protein (CHOP) in various cells [30]. The expression of DR5 is promoted by $\mathrm{CHOP}$ on biding to the promotor region of DR5 [30]. The present study found that A549 and NCI$\mathrm{H} 2170$ cells expressed significantly $(\mathrm{p}<0.05)$ enhanced CHOP and DR5 mRNA expression on vanillin oxime exposure. Vanillin oxime exposure also elevated CHOP protein level in A549 and NCI-H2170 cells. Moreover, CHOP and DR5 expression was significantly lowered in vanillin oxime exposed A549 and NCIH2170 cells on CHOP-siRNA transfection.

Stress is the major regulator for $\mathrm{CHOP}$ expression which is demonstrated by several studies investigating chemotherapeutic agents $[26,27]$. Up-regulated levels of CHOP protein and enhanced DR5 expression by oxidative stress has been demonstrated to induce TRAIL mediated apoptosis [26,27]. Among vital factors acting as downstream effectors of oxidative stress in tumor cells include MAPKs. During apoptosis mediated by TRAIL the levels of activated ERK and JNK are prominently higher [26,29]. The current study demonstrated that vanillin oxime exposure of A549 and NCI-H2170 cells led to significant $(\mathrm{p}<0.05)$ enhancement in levels of phosphorylated ERK and JNK. However, treatment of A549 and NCI-H2170 cells with JNK inhibitor (SP600125) as well as ERK1/2 inhibitor (PD98059) led to prominent reduction in vanillin oxime induced DR5 and DR4 levels.

In summary, vanillin oxime inhibits pulmonary cell proliferation via induction of apoptosis through TRAIL mediated pathway. Moreover, ERK/JNK pathway was activated whereas CHOP and DR5 expression was promoted in A549 and NCI-H2170 cells by vanillin oxime treatment. Therefore, vanillin oxime may be studied further to develop treatment for the lung cancer.

\section{CONFLICTS OF INTEREST}

The authors declare no conflicts of interest.

\section{REFERENCES}

1. Siegel R, Ma J, Zou Z, Jemal A. Cancer statistics, 2014. CA Cancer J Clin. 2014;64:9-29.

2. Herbst RS, Heymach JV, Lippman SM. Lung cancer. N Engl J Med. 2008;359:1367-1380.

3. Brambilla E, Gazdar A. Pathogenesis of lung cancer signalling pathways: roadmap for therapies. Eur Respir J. 2009;33:1485-1497.

4. Ashkenazi A, Pai RC, Fong S, Leung S, Lawrence DA, Marsters SA, Blackie C, Chang L, McMurtrey AE, Hebert A, DeForge L, Koumenis IL, Lewis D, Harris L, Bussiere J, Koeppen H, Shahrokh Z, Schwall RH. Safety and antitumor activity of recombinant soluble Apo2 ligand. J Clin Invest. 1999;104:155-162.

5. Sheridan JP, Marsters SA, Pitti RM, Gurney A, Skubatch M, Baldwin D, Ramakrishnan L, Gray CL, Baker K, Wood WI, Goddard AD, Godowski P, Ashkenazi A. Control of TRAIL-induced apoptosis by a family of signaling and decoy receptors. Science. 1997;277:818-821.

6. Pan G, Ni J, Wei YF, Yu G, Gentz R, Dixit VM. An antagonist decoy receptor and a death domain-containing receptor for TRAIL. Science. 1997;277:815-818.

7. Emery JG, McDonnell P, Burke MB, Deen KC, Lyn S, Silverman C, Dul E, Appelbaum ER, Eichman C, DiPrinzio R, Dodds RA, James IE, Rosenberg M, Lee JC, Young PR. Osteoprotegerin is a receptor for the cytotoxic ligand TRAIL. J Biol Chem. 1998;273:14363-14367.

8. Nagata S. Apoptosis by death factor. Cell. 1997;88:355-365.

9. Zhang L, Fang B. Mechanisms of resistance to TRAIL-induced apoptosis in cancer. Cancer Gene Ther. 2005;12:228-237.

10. Sanlioglu AD, Dirice E, Aydin C, Erin N, Koksoy S, Sanlioglu S. Surface TRAIL decoy receptor- 4 expression is correlated with TRAIL resistance in MCF7 breast cancer cells. BMC Cancer. 2005;5:54.

11. Griffith TS, Kucaba TA, O'Donnell MA, Burns J, Benetatos C, McKinlay MA, Condon S, Chunduru S. Sensitization of human bladder tumor cells to TNF-related apoptosis-inducing ligand (TRAIL)-induced apoptosis with a small molecule IAP antagonist. Apoptosis. 2011;16:13-26.

12. Walton NJ, Mayer MJ, Narbad A. Vanillin. Phytochemistry. 2003;63: 
505-515.

13. King AA, Shaughnessy DT, Mure K, Leszczynska J, Ward WO, Umbach DM, Xu Z, Ducharme D, Taylor JA, Demarini DM, Klein CB. Antimutagenicity of cinnamaldehyde and vanillin in human cells: global gene expression and possible role of DNA damage and repair. Mutat Res. 2007;616:60-69.

14. Srinivasan K, Platel K, Rao MVL. Hypotriglyceridemic effect of dietary vanillin in experimental rats. Eur Food Res Technol. 2008;228:103-108.

15. Imanishi H, Sasaki YF, Matsumoto K, Watanabe M, Ohta T, Shirasu Y, Tutikawa K. Suppression of 6-TG-resistant mutations in V79 cells and recessive spot formations in mice by vanillin. Mutat Res. 1990;243:151-158.

16. Liang JA, Wu SL, Lo HY, Hsiang CY, Ho TY. Vanillin inhibits matrix metalloproteinase-9 expression through down-regulation of nuclear factor-kappaB signaling pathway in human hepatocellular carcinoma cells. Mol Pharmacol. 2009;75:151-157.

17. Lirdprapamongkol K, Sakurai H, Suzuki S, Koizumi K, Prangsaengtong O, Viriyaroj A, Ruchirawat S, Svasti J, Saiki I. Vanillin enhances TRAIL-induced apoptosis in cancer cells through inhibition of NF-kappaB activation. In Vivo. 2010;24:501-506.

18. Lirdprapamongkol K, Sakurai H, Kawasaki N, Choo MK, Saitoh Y, Aozuka Y, Singhirunnusorn P, Ruchirawat S, Svasti J, Saiki I. Vanillin suppresses in vitro invasion and in vivo metastasis of mouse breast cancer cells. Eur J Pharm Sci. 2005;25:57-65.

19. Lirdprapamongkol K, Kramb JP, Suthiphongchai T, Surarit R, Srisomsap C, Dannhardt G, Svasti J. Vanillin suppresses metastatic potential of human cancer cells through PI3K inhibition and decreases angiogenesis in vivo. J Agric Food Chem. 2009;57:3055-3063.

20. Yadav VR, Sung B, Prasad S, Kannappan R, Cho SG, Liu M, Chaturvedi MM, Aggarwal BB. Celastrol suppresses invasion of colon and pancreatic cancer cells through the downregulation of expression of CXCR4 chemokine receptor. J Mol Med. 2010;88:12431253.

21. Tsuda $H$, Uehara N, Iwahori $Y$, Asamoto M, Iigo M, Nagao M, Matsumoto $\mathrm{K}$, Ito M, Hirono I. Chemopreventive effects of beta-carotene, alpha-tocopherol and five naturally occurring antioxidants on initiation of hepatocarcinogenesis by 2-amino-3-methylimidazo [4,5-f] quinoline in the rat. Jpn J Cancer Res. 1994;85:1214-1219.

22. Durant S, Karran P. Vanillins--a novel family of DNA-PK inhibitors. Nucleic Acids Res. 2003;31:5501-5512.

23. Gustafson DL, Franz HR, Ueno AM, Smith CJ, Doolittle DJ, Waldren CA. Vanillin (3-methoxy-4-hydroxybenzaldehyde) inhibits mutation induced by hydrogen peroxide, N-methyl-N-nitrosoguanidine and mitomycin $\mathrm{C}$ but not (137)Cs gamma-radiation at the CD59 locus in human-hamster hybrid A(L) cells. Mutagenesis. 2000;15:207-213.

24. Chawla-Sarkar M, Bae SI, Reu FJ, Jacobs BS, Lindner DJ, Borden EC. Downregulation of Bcl-2, FLIP or IAPs (XIAP and survivin) by siRNAs sensitizes resistant melanoma cells to Apo2L/TRAILinduced apoptosis. Cell Death Differ. 2004;11:915-923.

25. Deveraux QL, Takahashi R, Salvesen GS, Reed JC. X-linked IAP is a direct inhibitor of cell-death proteases. Nature. 1997;388:300-304.

26. Gupta SC, Reuter S, Phromnoi K, Park B, Hema PS, Nair M, Aggarwal BB. Nimbolide sensitizes human colon cancer cells to TRAIL through reactive oxygen species- and ERK-dependent up-regulation of death receptors, p53, and Bax. J Biol Chem. 2011;286:1134-1146. Retraction in: Gupta SC. J Biol Chem. 2016;291:16925.

27. Moon DO, Park SY, Choi YH, Ahn JS, Kim GY. Guggulsterone sensitizes hepatoma cells to TRAIL-induced apoptosis through the induction of CHOP-dependent DR5: involvement of ROS-dependent ER-stress. Biochem Pharmacol. 2011;82:1641-1650.

28. Fisher MJ, Virmani AK, Wu L, Aplenc R, Harper JC, Powell SM, Rebbeck TR, Sidransky D, Gazdar AF, El-Deiry WS. Nucleotide substitution in the ectodomain of trail receptor DR4 is associated with lung cancer and head and neck cancer. Clin Cancer Res. 2001;7:1688-1697.

29. Mellier G, Huang S, Shenoy K, Pervaiz S. TRAILing death in cancer. Mol Aspects Med. 2010;31:93-112.

30. Lin N, Sato T, Takayama Y, Mimaki Y, Sashida Y, Yano M, Ito A. Novel anti-inflammatory actions of nobiletin, a citrus polymethoxy flavonoid, on human synovial fibroblasts and mouse macrophages. Biochem Pharmacol. 2003;65:2065-2071. 